\title{
Patient and Relative Complaints in a Hospital Emergency Department: A 4-Year Analysis
}

\author{
Bir Hastane Acil Servisinde Hasta ve Yakını \\ Şikâyetleri: 4 Yıllık Analiz
}

\author{
Suat ZENGIN, Behçet AL, Erdal YAVUZ, Cem ŞEN, Şener CiNDORUK, Cuma YILDIRIM \\ Gaziantep University Faculty of Medicine, Gaziantep
}

\begin{abstract}
SUMMARY
\section{Objectives}

Complaints by patients and their relatives are an important source of information for service improvement. In order to take remedial measures, the present study evaluated the complaints of patients and their relatives about our emergency department (ED).

\section{Methods}

Records of all patient complaints, from June 2008 to June 2012, were retrieved from the Quality Improvement Unit (QIU) archives. All complainants were contacted by phone. The socio-demographic profiles of complainants, their reasons for complaints, and the outcomes were analyzed using the SPSS statistical package.
\end{abstract}

\section{Results}

The results revealed that 54 complaints have been made against our ED over four years relating to medical care, staff attitudes, waiting time, and financial reasons. Of the complainants, $75.9 \%$ were male $(n=41)$, and $24.1 \%(n=13)$ were female. The majority $(29.7 \%, 20.4 \%)$ of the complaints were due to medical care and attitude problems. Most complaints were made for green code patients (55.6\%). The majority of complaints were about emergency physicians (38.9\%). Complaint frequency was 0.18 per 1.000 visits.

\section{Conclusions}

Complaints are potentially useful quality assurance tools, and can identify remediable system flaws. The main causes of complaints are medical care, staff attitude, and waiting time, and many of these causes are remediable.

Key words: Complaint rate; emergency department; patient complaints; staff-patient communication.

\section{ÖZET}

Amaç

Hasta ve yakınlarının şikâyetleri, hizmet iyileștirmeleri için önemli bir bilgi kaynağıdır. Bu çalışmada; düzeltici önlemler almak amacıyla, hasta ve yakınlarının acil servis hakkında şikâyetleri değerlendirildi.

\section{Gereç ve Yöntem}

Kalite Geliştirme Birimi (KGB) arşivinden Haziran 2008 ile Haziran 2012 yılları arasındaki tüm hasta şikâyetlerinin kayıtları alındı. Tüm şikâyetçilerle telefonla bağlantı kuruldu Şikâyetçilerin sosyo-demografik profilleri, şikâyet nedenleri ve sonuçları SPSS istatistiksel paket programı kullanılarak analiz edildi.

\section{Bulgular}

Sonuçlar, dört yılda tıbbi bakım, personel tutumu, bekleme süresi ve mali sebeplerle ilgili acil servise karşı yapılmış 54 şikâyetin olduğunu ortaya çıkardı. Şikâyetçilerin, \%75.9'u (n=41) erkek, \%24.1'i (n=13) kadındı. Şikâyetlerin büyük bir kısmı (\%29.7-\%20.4) tıbbi bakım ve davranış problemlerine bağlıydı. Çoğu şikâyet yeşil kodlu hastalar için yapılmıştı (\%55.6). Şikâyetlerin çoğu acil doktorları hakkındaydı (\%38.9). Şikâyet sıklığı; her 1.000 başvuruya 0.18 idi.

\section{Sonuç}

Şikâyetler potansiyel olarak kullanışlı kalite ölçme araçlarıdır ve sistemin düzeltilebilir kusurlarını belirleyebilir. Şikâyetlerin ana nedenleri tıbbi bakım, personel tutumu ve bekleme süresidir ve bu nedenlerin çoğu düzeltilebilir.

Anahtar sözcükler: Hasta şikâyetleri; acil servis; personel-hasta iletişimi; şikayet oranı. 


\section{Introduction}

There is an apparent perception that the emergency department (ED) is one the most difficult departments of a hospital, therefore it is not a preferred workplace. However, the ED is a very important department as it is the "shop window and front door" of the hospitals. In 2009, 27\% of the total hospital admissions in Turkey were through the ED and this rate is increasing. ${ }^{[1]}$

Complaints against ED staff are not rare. EDs with long waiting times, junior staff, and a focus on acute care have the potential to generate significant patient complaints. Patients complain for various reasons if they become dissatisfied with the service. These complaints may result from unmet expectations or may reflect poor service quality. Health practitioners often perceive them in a negative light, and complaints can sometimes have a devastating effect on individuals and organizations. However, complaints can be seen as an advantage, acting as a benchmark to assess quality of care, make interventions, and minimize the number of complaints. Quantitative measurement of patient complaints is a comparative measure of service quality, and several authorities believe quality assurance measures should include patient satisfaction and an analysis of patient complaints. ${ }^{[2]}$ However, it is evident that the hospitals do not use patient complaints as a source of learning to promote higher standards of care. ${ }^{[3]}$

Consumers are becoming better informed and more aware of their rights, leading to a rise in complaints about the quality of healthcare. It is therefore necessary to encourage further research to ensure more appropriate use of patient complaints.

Our hospital has 940 beds and three intensive care units with 110 beds. We have 20 sedan chairs (12 for first examination, 2 in resuscitation room, 2 in surgery intervention room, 2 in cardiologic observation room, one orthopedic and gynecologic room, one in ultrasonography room) and 12 beds ( 6 for females and 6 for males) in our ED. Approximately 75.000 patients are admitted to the ED annually. This number does not include pediatric ( $<16$ year-old) patients. Currently, 20 physicians, 12 intern doctors, 16 nurses, and 25 non-medical staff working in the ED. We analyzed data on patient complaints relating to our ED between June 2008 and June 2012. The purposes of this study are to analyze the types of complaints received by the ED so steps can be taken to minimize them in future, to enable hospital administration to understand the difficulties faced by the ED, and to let new physicians in the ED know the pitfalls involved in the practice of emergency medicine.

\section{Materials and Methods}

The study entailed a retrospective analysis of complaints relating to the care of patients seen in Gaziantep University
ED between 1 June 2008 and 1 June 2012. The study was approved by the Medical Ethics Committee of Gaziantep University.

In May 2004, the hospital set up a complaint department as part of a quality improvement system that deals with all formal complaints, whether made verbally, in writing, by telephone, or through other forms of electronic communication received by the Health Ministry Communication Center (HMCC) and Prime Minister's Communications Center (PMCC). The complaint department benefits from a civil servant who is selected from the experienced employees according to the following criteria:

- Being familiar with the work flow of different hospital units;

- Good public relations and desirable work relations with the majority of the staff;

- Being tolerant and a good listener.

Information relating to the origin, nature, and outcome of complaints is entered into a computerized database by this civil servant. The complaint data for the current study were obtained from the Quality Improvement Unit (QIU) archives of our hospital. The socio-demographic profiles of complainants, their reasons for complaints, and the outcomes were recorded and analyzed. The diagnosis of patients were received the hospital automation records, and the triage code was made by using these diagnosis. In triage evaluation, code yellow and red patients were categorized as emergency patients, and code green patients were categorized as non-emergency. All complainants were contacted by phone.

These complaints were categorized under the following headings:

I. Medical care (dissatisfaction with examination and treatment, misdiagnosis)

II. Long waiting time

III. Medical and paramedical staff-patient and patient-relatives relationships

IV. Financial affairs

V. Other

The frequencies of the data were analyzed using SPSS for Win. Ver. 18.0 (SPSS Inc., Chicago, Illinois, USA).

\section{Results}

Between 1 June 2008 and 1 June 2012, 300.417 patients were admitted our ED. In the period, 2.212.697 patients were admitted to the hospital, and the hospital received 489 complaints, 54 (11\%) of which concerned the ED. For ED, while complaint frequency was 0.18 per 1.000 visits, for hospital was 0.22 per 1.000 visits. Of complaint applications, 
41 were made to QIU, 9 to the HMCC, and 4 to the PMCC. Of complainants, 41 (75.9\%) were male and $13(24.1 \%)$ were female (Table 1). The majority of complainants were

Table 1. The demographic distribution of complainants

\begin{tabular}{lccc}
\multicolumn{3}{l}{ The relationship between gender and complaints } \\
\hline Gender & $\mathbf{n}$ & $\%$ & $\begin{array}{c}\text { Complaint case rate } \\
\text { (per 1.000 visits) }\end{array}$ \\
\hline Male & 41 & 75.9 & 0.14 \\
Female & 13 & 24.1 & 0.04 \\
\hline
\end{tabular}

The relationship between age and complaints

\begin{tabular}{lccc}
\hline Age & $\mathbf{n}$ & $\%$ & $\begin{array}{c}\text { Complaint case rate } \\
\text { (per 1.000 visits) }\end{array}$ \\
\hline$\leq 20$ & 8 & 15 & 0.03 \\
$21-40$ & 33 & 61 & 0.11 \\
$41-60$ & 12 & 22 & 0.04 \\
$\geq 61$ & 1 & 2 & 0.00 \\
\hline
\end{tabular}

The relationship between occupation of complainants and complaints

\begin{tabular}{lccc}
\hline Occupation & $\mathbf{n}$ & $\%$ & $\begin{array}{c}\text { Complaint case rate } \\
\text { (per 1.000 visits) }\end{array}$ \\
\hline Civil servant & 15 & 27.8 & 0.05 \\
Worker & 11 & 20.4 & 0.04 \\
Student & 10 & 18.5 & 0.03 \\
Self-employed & 7 & 13 & 0.00 \\
Retired & 7 & 13 & 0.02 \\
Housewife & 2 & 3.7 & 0.02 \\
\hline
\end{tabular}

The relationship between educational status and complaints

\begin{tabular}{lccc}
\hline Educational status & $\mathbf{n}$ & $\%$ & $\begin{array}{c}\text { Complaint case rate } \\
\text { (per 1.000 visits) }\end{array}$ \\
\hline High school & 22 & 40.7 & 0.07 \\
University & 18 & 33.3 & 0.06 \\
Primary school & 9 & 16.7 & 0.03 \\
Secondary school & 4 & 7.4 & 0.01 \\
Military academy & 1 & 2 & 0.00 \\
\hline Relationship between the complainant and patient \\
\hline Kinship & $\mathbf{n}$ & $\%$ & Complaint case rate \\
& & & (per 1.000 visits) \\
\hline Self & 25 & 46.3 & 0.08 \\
Child & 8 & 14.8 & 0.03 \\
Spouse & 7 & 13 & 0.02 \\
Friend & 7 & 13 & 0.02 \\
Other & 5 & 9.3 & 0.02 \\
Parent & 1 & 2 & 0.00 \\
Sibling & 1 & 2 & 0.00 \\
\hline
\end{tabular}

civil servants $(27.8 \%, \mathrm{n}=15)$, and had graduated from high school $(40.7 \%, n=22)$ (Table 1$)$. The majority of complaints were made about emergency physicians (38.9\%) (Table 2). The majority (42.7\%) of the complaints were due to medical care and communication problems (Table 2). The number of staff that worked in ED according to years are: June 2008May 2009; 14 physicians, 15 nurses, 20 non-medical staff, June 2009-May 2010; 12 physicians, 15 nurses, 20 non-medical staff, June 2010-May 2011; 10 physicians, 14 nurses, 20 non-medical staff, and June 2011-May 2012; 17 physicians, 16 nurses, 25 non-medical staff. The majority of complaints (33.3\%, $\mathrm{n}=18)$ were made between June 12010 and May 31 2011 (Table 3). Most complaints were made for green code patients $(55.6 \%)$. The majority of complaints $(59.3 \%, \mathrm{n}=32)$ occurred on days that the patients were examined more than the mean of month (Table 4). Complainants stated the names of 13 physicians out of 21 they complained about. Six of these complaints were about $X, 4$ were about $Y$, and 3 were about Z-named physicians.

Table 2. The staff who were complained and causes of complaint

\begin{tabular}{lcc} 
The staff who were complained & & \\
\cline { 1 - 2 } Staff & n & $\%$ \\
\hline Physician & 21 & 38.9 \\
Consultant & 11 & 20.4 \\
Cashier & 7 & 13 \\
Nurse & 5 & 9.3 \\
Other & & \\
$\quad$ Hospital administration & 1 & 1.9 \\
$\quad$ CT technician & 5 & 9.3 \\
$\quad$ Security personnel & 3 & 5.6 \\
Auxiliaries & 1 & 1.9
\end{tabular}

\section{Main issues of the complaints}

\begin{tabular}{lcc} 
Reason & $\mathbf{n}$ & $\%$ \\
\hline Medical care & & \\
$\quad$ Dissatisfaction with treatment & 9 & 16.7 \\
$\quad$ Misdiagnosis & 4 & 7.4 \\
$\quad$ Dissatisfaction examination & 3 & 5.6 \\
Poor attitude & 11 & 20.4 \\
Long waiting time & 7 & 13 \\
Financial affair & 5 & 9.3 \\
Other & & \\
$\quad$ The lack of an empty bed & 10 & 18.5 \\
$\quad$ Poor physical environment & 3 & 5.6 \\
$\quad$ Loss of patient files & 1 & 1.9
\end{tabular}

QIU: Quality Improvement Unit; HMCC: Health Ministry Communication Center; PMCC: Prime Minister's Communications Center. 
Table 3. Distribution of complaints according to years

\begin{tabular}{lcccc}
\hline Complainants per year and rates per $\mathbf{1 . 0 0 0}$ new cases & & & \\
\hline Year & $\mathbf{n}$ & $\%$ & $\begin{array}{c}\text { Total no. of } \\
\text { patients seen }\end{array}$ & $\begin{array}{c}\text { Complaint case rate } \\
\text { (per 1.000 visits) }\end{array}$ \\
\hline June 1 2008-May 312009 & 9 & 16.7 & 57455 & 0.16 \\
June 1 2009-May 31 2010 & 13 & 24.1 & 66622 & 0.20 \\
June 1 2010-May 31 2011 & 18 & 33.3 & 79943 & 0.23 \\
June 1 2011-May 31 2012 & 14 & 25.9 & 96397 & 0.14 \\
\hline
\end{tabular}

Table 4. The relationship between triage code, examination day, examination time and complaints

\begin{tabular}{lcccc}
\hline \multicolumn{2}{l}{ The relationship between triage code and complaints } & \\
\hline Triage code & $\mathbf{n}$ & $\%$ & Complaint case rate (per 1.000 visits) \\
\hline Green & 30 & 55.6 & 0.10 \\
Yellow & 8 & 14.8 & 0.03 \\
Red & 16 & 29.6 & 0.05
\end{tabular}

The relationship between examination day and complaints

\begin{tabular}{lccc} 
Day & $\mathbf{n}$ & $\%$ & Complaint case rate (per 1.000 visits) \\
\hline Monday & 18 & 33.3 & 0.06 \\
Tuesday & 6 & 11.1 & 0.02 \\
Wednesday & 6 & 11.1 & 0.02 \\
Thursday & 5 & 9.3 & 0.01 \\
Friday & 9 & 16.7 & 0.03 \\
Saturday & 4 & 7.4 & 0.01 \\
Sunday & 6 & 11.1 & 0.02
\end{tabular}

The relationship between examination time and complaints

\begin{tabular}{lccc}
\hline Hour & $\mathbf{n}$ & $\%$ & Complaint case rate (per 1.000 visits) \\
\hline 08:00-16:00 & 21 & 38.9 & 0.07 \\
16:00-00:00 & 30 & 55.6 & 0.10 \\
00:00-08:00 & 3 & 5.6 & 0.01 \\
\hline
\end{tabular}

The status of patients examined daily according to a monthly average the seen per day and complaints

\begin{tabular}{lcccc}
\hline Number of patients seen per a day & $\mathbf{n}$ & $\%$ & Complaint case rate (per 1.000 visits) \\
\hline Less than monthly average & 22 & 40.7 & 0.07 \\
More than monthly average & 32 & 59.3 & 0.11 \\
\hline
\end{tabular}

\section{Discussion}

A complaint is a condition or expression of dissatisfaction with, for example, staff, procedures, fees, and quality care. In this study, we investigated the proportion of admissions with written and electronic complaints, the type of complaint, and the outcomes of the complaint process in the ED over a 48-month period.

Other investigators have reported ED complaint rates rang- ing from 0.16 to 3.8 complaints/1.000 patients. ${ }^{[2,4-7]}$ For example, while Ooi et al. found this ratio 0.26 per 1.000 , Schwartz et al. found 3.8 per 1.000. The complaint case rate found in this study $(0.18$ per 1.000$)$ is comparable with rates reported by others. In contrast to other studies, the men in our study complained significantly more frequently than women. ${ }^{[2,4-7]}$ The reasons for this apparent gender difference are not clearly known and, as the data were only available in summary form, it precludes further analysis. However we think it may 
be associated with us not treating patients under 16 years old. In addition, the finding that close relatives and friends were the complainants in half of the cases was surprising, and is not consistent with the findings of others. ${ }^{[2,4-7]}$ While complaints over the last 4 years show a rise to 18 between June 2010 and June 2011, the numbers of complaints between June 2011 and June 2012 has declined. While there were 10 physicians working between June 2010 and June 2011 in the ED, there were 17 physicians working between June 2011 and June 2012. This decline in the number of complaints could be related to the number of physicians working.

The majority of the complaints were directly related to medical care. Also, a significant amount of complaints was about poor attitude of staff, and most of these complaints were made about the emergency physicians. These results are similar with rates reported by others. ${ }^{[2,4-7]}$ In most cases we can prevent patients' complaints through careful examination and a good communication. We believe that communication issue should be included in medical education and in ED orientation programs to educate physicians on appropriate communication skills between patients and physicians.

The majority of the complaints were about patients treated between 16:00 and 00:00 hours, the period most ED admissions occur. There were more complaints about patients who examined on Mondays and Fridays compared to other days. It appears this may be because patients arrive in the ED on Monday if they have not made an appointment with a polyclinic and on Friday if they could not complete their polyclinic examinations. These factors increase complaints. Therefore, in these times, the number of the staffs working in the ED should be increased to decrease complaints. For this purpose, more staff should be requested from hospital administration.

Complaints were higher from code green patients $(55.6 \%$, $\mathrm{n}=30$ ) than others. Patients often expect prompt service in the ED as they tend to view their complaints (however minor from a medical standpoint) to be an emergency. Many patients do not understand the concept of triage in the ED. We think staffs not showing enough attention to patients who are not emergent increases complaints.

Approximately one-sixth of the complaints were related to waiting time. In many healthcare systems, there are waiting lists, and normally the main reason for the waiting time is a lack of resources. Therefore, a proportion of these complaints may be the result of an unrealistic expectation by the patient, but because patients' overall satisfaction is partly determined by the perceived rather than actual waiting time, this is important to consider and to explain to the patients. ${ }^{[4]}$ We believe that the number of complaints may be decreased by increasing the number of staffs working in the
ED or making an explanation about the capacity of ED.

According to many studies; although there are many causes, the main cause for complaint is staff attitude towards patients and their relatives. ${ }^{[8-11]}$ In our study, $20.4 \%$ of complaints were about the attitude of staffs. Improper attitudes affect patient satisfaction and compliance to treatment. Therefore the staff should communicate sufficiently with the patient, inform them about the process, and avoid unnecessary arguments with those who arrive at the ED in a state of panic.

Only 17 of 48 (all electronic applications) complainants who could be reached by phone had received feedback about their complaints. None of the 31 complainants who applied in writing had received feedback. These 31 complainants expressed dissatisfaction due to no feedback. To increase satisfaction of patients and relatives, about complaints should be made feedback to the complainants.

The results of our study were presented the as an outcome report to the hospital management, and correction of deficiencies related to the hospital administration was requested from administration (increasing number of staff, increasing the number of patient beds etc.). The training courses related to communication and attitude were planned for all ED staffs. An education was given to all staffs about the problems of the patients and relatives. In addition, the physicians those were complained frequently were warned, and individual conversations were carried out with them.

\section{Limitations}

The present study has several limitations. First, complaints are often complex and some may have been incorrectly categorized, leading to measurement bias. No objective standard to classify complaints is available. Second, the results are subject to selection bias. It is possible that some complaints were not passed on to hospital complaint department officers, and that the data underrepresents the true complaint rates.

\section{Conclusion}

Complaints are potentially useful quality assurance tools. A study of complaints may help identify gaps in our services in order to make necessary corrections to policies or procedures. The main causes of the complaints were insufficient medical care, appropriate attitude and long waiting time which are result of high number of patients, insufficient of staff and patients with green code. Many of these causes can be resolved.

\section{Conflict and Interest}

The authors declare that there is no potential conflict of interest. 


\section{References}

1. Arslanhan S. Muayene sayısındaki artış, anlamlı bir erişim artışını mı ifade ediyor? Available at: http://www.tepav.org.tr/ upload/files/1284627104-1. Muayene_sayisindaki_artis_anlamli_bir_erisim_artisini_mi_ifade_ediyor.pdf. Accessed July 3.2012.

2. Taylor DM, Wolfe RS, Cameron PA. Analysis of complaints lodged by patients attending Victorian hospitals, 1997-2001. Med J Aust 2004;181:31-5.

3. Hsieh SY, Thomas D, Rotem A. The organisational response to patient complaints: a case study in Taiwan. Int J Health Care Qual Assur Inc Leadersh Health Serv 2005;18:308-20.

4. Wong LL, Ooi SB, Goh LG. Patients' complaints in a hospital emergency department in Singapore. Singapore Med J 2007;48:990-5.

5. Schwartz LR, Overton DT. Emergency department complaints: a one-year analysis. Ann Emerg Med 1987;16:857-61.
6. Salazar A, Ortiga B, Escarrabill J, Corbella X. Emergency department complaints: a 12 year study in a university hospital. Ann Emerg Med 2004; 44: Supp1 ACEP Research Forum.

7. Ooi SB. Emergency department complaints: a ten-year review. Singapore Med J 1997;38:102-7.

8. Hunt MT, Glucksman ME. A review of 7 years of complaints in an inner-city accident and emergency department. Arch Emerg Med 1991;8:17-23.

9. Bazrafkan L, Shokrpour N, Tabeie SZ. A survey of patients complaints against physicians in a five year period in Fars province: implication for medical education. Journal of Medical Education Winter and Spring 2008;12:23-8.

10. Wong LL, Ooi SB, Goh LG. Patients' complaints in a hospital emergency department in Singapore. Singapore Med J 2007;48:990-5.

11. Kadzombe EA, Coals J. Complaints against doctors in an accident and emergency department: a 10-year analysis. Arch Emerg Med 1992;9:134-42. 